\title{
CHANGES IN LAND USE FOR PRODUCTION OF ENERGY CROPS IN POLAND
}

\author{
Ludwik Wicki \\ Department of Economics and Organisation of Enterprises of Warsaw University \\ of Life Science - SGGW \\ Head of Department: Prof. dr hab. Henryk Runowski
}

\begin{abstract}
Key words: bioenergy, bioethanol, biodiesel, biogas, food - energy competition
Stowa kluczowe: bioenergia, bioetanol, biodiesel, biogaz, konkurencja żywność - energia

A bs tr a ct. The goal of the article is to evaluate whether production of modern biofuels in Poland competes with food production. CSO and AMA data have been used in the analysis. The data in question refers to the area of arable land in Poland, yields and livestock as well as renewable energy production structure and quantity and production of biodiesel, bioethanol and agricultural biogas. Data concerning quantity of raw materials used for production of the agricultural biogas have been accessed from AMA. Data for 2005-2016 have been collected. Production of bioenergy based on agricultural raw materials has significantly increased. From 2005 to 2016, it increased from 5 to 42 TJ. Approximately $92 \%$ of bioenergy from agricultural sources are bioethanol and biodiesel produced from the first generation of raw materials, the production of which is in direct competition with food production. The share of biogas was $8 \%$ only. Waste constituted $75 \%$ in the raw materials used to produce biogas. The area of production of energy crops has reached $5.6 \%$ of arable land in 2016 from $1.5 \%$ in 2005. It means that in Poland production of bioenergy from agricultural sources competes with food and feed production and its further increase is not desirable. Actions focused on the increased use of the second generation raw materials for energy production and decreased use of food raw materials should be taken.
\end{abstract}

\section{INTRODUCTION}

Increased demand for energy in the world becomes a reason to search for new energy sources. Additionally, it is expected that new energy sources will create lower emissions as well as they will be renewable sources. The energy coming from renewable sources includes energy of water, wind, sun, geothermal and biofuels. In some applications, e.g. in transport liquid biofuels, it has become the only substitute for fossil fuels. The biofuels production opportunities have been known for many decades so far, but their production on industrial scale became cost-effective only when crude oil prices increased to very high levels and when low emission economy concept started to be followed. Production of fuels is considered one of the most important directions for development the modern concept of bioeconomy.

In the multifunctional use of agricultural land, there are a number of options relating to the production of biomass: food crops used for bioenergy; crop residues of annual cereals 


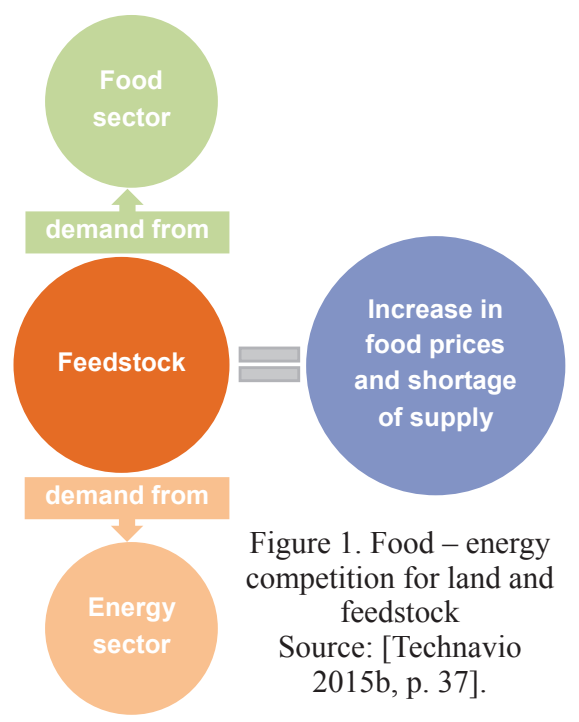

used for bioenergy, whereas the grain is used for food, feed or bioenergy; dedicated lignocellulosic 'next generation' perennial energy crops grown for their high yields of biomass [Valentine at al. 2012]. The use of the grain of agriculture crops for bioenergy competes directly with their use for food (fig. 1). This is perceived as morally wrong and risks causing prices of food to rise as supplies tighten. Use of grain for bioenergy may be more acceptable where there are exportable surpluses such as in more well-off developed countries. Such use can become disastrous in developing nations with low developed farming systems and supply chains. According to Technavio [2015a] report, about 5 percent of agriculture land worldwide is used for bioenergy production, 58 percent for food production and 37 percent for animal feed production.

Bioenergy draws on a wide range of potential feedstock materials: forestry and agricultural residues and wastes of many sorts, as well as material grown specifically for energy purposes. The raw materials can be converted to heat for use in buildings and industry, to electricity, or into gaseous or liquid fuels, which can be used in transport, for example. This degree of flexibility is unique amongst the different forms of renewable energy.

The most commonly used conversion methods - combustion of fuels to produce heat or electricity; anaerobic digestion to produce methane for heat or power production; and the conversion of sugary and starchy raw materials to ethanol, or of vegetable oils to biodiesel - all are well-established and commercial technologies. A further set of conversion processes - for example, the production of liquid fuels from cellulosic materials by biological or thermochemical conversion processes, such as pyrolysis - are at earlier stages of commercialisation or still under development.

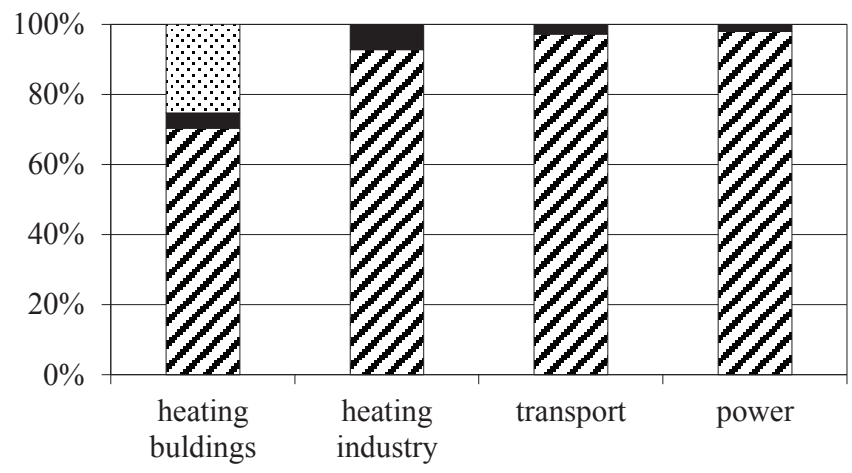

a Non-biomass
- Modern biomass
Figure 2. Shares of biomass in final energy consumption by end-use sector, 2014 Source: [REN21 2016]. 
The bioenergy share in total global primary energy consumption has remained relatively steady since 2005 , at around $14 \%$, despite a $24 \%$ increase in overall global energy demand between 2005 and 2015 [REN21 2016].

Solid biomass represents the largest share of biomass used for heat and electricity generation, whereas liquid biofuel represents the largest source in the transport sector (fig. 2).

Only $10 \%$ of the total quantity of biomass used for energy production comes from agriculture. The highest share, ca. $40 \%$ belongs to by-products of plant origin, $30 \%$ belongs to waste of animal origin and energy crops [IPCC 2012].

Two most popular biofuels globally are bioethanol and biodiesel; other biofuels include butane, Fischer-Tropsch diesel, syngas, and biogas. Bioethanol is made from wheat, corn, sugarcane etc., and biodiesel is made from oil seeds such as soybeans, rape seed, and palm oil. The feedstock used in the production of biofuels is also used for human and animal consumption, affecting food crop prices. Biofuels production process has been accompanied by a threat of food price increase resulting from competitive application of agricultural raw materials used for foodstuff or biofuels production. In some analysis possibility of increasing bioenergy production is indicated, but they still ask the question is how we can use bioenergy without jeopardizing food production, carbon sinks and biodiversity. Second generation of biofueles, like perennial lignocellulose energy crops, such as Miscanthus and willow will reduce direct competition with food. It is underlined that there are necessary improved models and scenarios to determine how much food and fuel can be produced from a finite land resource.

First generation biofuels are produced using vegetable oil, animal fat, and used cooking oil. The feedstock used in producing biofuels is also used as food, and the prices of these feedstocks are directly associated with the demand from biofuels creating conflict between the food and energy sectors. This continuous issue has led to the development of second and third generation biofuels to overcome the limitations of first generation fuels. Second generation fuels are produced using non-food crops like wood (sawdust), organic waste (corn stover) and specific biomass plants such as jatropha, camelina, and switchgrass. The third and fourth generation fuel, also called advanced biofuel, is produced using specially engineered energy crops like algae as feedstock, which provides higher yield with lower resource inputs [TechNavio 2015b]. Fourth generation of feedstock for biofuels production is still in laboratory stage, so we don't know yet what kind of organisms will be developed with use of genetic engineering methods. In table 1, short classification of raw materials used for biofuels production has been presented.

It is recommended to reduce production of the first generation biofuels, i.e. manufactured using the same raw materials as during food production, in connection with competitive effect that appears between biofuels production and food production [Nelson 2010].

Table 1. Generation of biofuels

\begin{tabular}{cccc}
\hline 1st generation & 2nd generation & 3rd generation & 4th generation \\
\hline Cereals & Organic waste & Micro-algae & $\begin{array}{c}\text { Genetically modified } \\
\text { feedstocks }\end{array}$ \\
Rape & Non-food crops & Seaweed & \\
Palm oil & Cellulosic waste & & \\
Soybean oil & & & \\
Corn & & & \\
\hline
\end{tabular}

Source: author's study. 
Even so, the global production is still growing. Production of liquid biofuels reached the level of 133 billion litres in 2015 and it was 3\% higher than in 2014. More than $74 \%$ of the global production of liquid biofuels is constituted by bioethanol, biodiesel $22 \%$ and other advanced biofuels $4 \%$. The biggest global manufacturer is the USA where $46 \%$ of the global biofuels production is manufactured, then Brazil constituting 24\% share and EU $-15 \%$. The USA share in the global bioethanol production is ca. $50 \%$, and $25 \%$ ca. is Brazil share. The European Union (EU) takes the fourth place, following China that constitutes $6 \%$. As far as biodiesel production is concerned, the first place is taken by the EU with $42 \%$ share and it is followed by the USA - 18\% and Brazil - $11 \%$ [OECD/FAO 2015, 2016]. Biodiesel production in the EU has been developed due to support provided by the Common Agricultural Policy, but also in connection with the Directive on transportation. It is manufactured from rapeseed, so its production competes with foodstuff production. Biofuels production in the EU are not related to macro-economic indicators in the Member States. High consumption of renewable energy in the EU results from the conducted environmentally-friendly policy [European Communities 2009, Rokicki 2016].

\section{AIM AND METHODS}

The aim of the paper is to evaluate whether production of modern biofuels competes with food production in Poland The goal has been achieved due to implementation of three scientific tasks: 1) determination of raw materials quantities of agricultural origin used for production of modern biofuels; 2) determination of the agricultural crops area where production is used to produce biofuels; 3 ) determination of the agricultural area share used to produce biofuels and determination of the share change ratio.

Central Statistical Office of Poland (CSO) and Agricultural Market Agency (AMA) data have been used in the analysis. Data coming from the CSO statistics referred to the agricultural areas in Poland, average yields and livestock. Data regarding quantity and energy production mix coming from renewable energy sources, including production of biodiesel, bioethanol and agricultural biogas, have also been collected. Data concerning quantity of raw materials used for production of the agricultural biogas have been accessed from AMA. Data for 2005-2016 have been collected. There is no comparable statistical data for the previous years. It has been assumed that from oilseed rape we obtain on average $40 \%$ of oil and from 1 ton of cereal grains we obtain 3401 of ethyl alcohol. Additionally only $50 \%$ of oilseed rape area was counted as dedicated for biodiesel production, because of rape cakes are used as a feed for animals. The subject of the study is the agricultural area utilized directly for the production of raw materials for biofuel production and its share in the total agricultural area in Poland. The object of the study is therefore crop production in Poland.

Agricultural area used to produce raw materials necessary in biofuels production process has been determined considering main crops. Due to short series of data, the results have been presented in tables and in a descriptive form. There is no reason to apply statistical methods. Additionally, there is no price analysis because prices on Polish agricultural market strongly depend on situation on whole European market, so much wider analysis is necessary to explain influence of biofuels market size on food market prices. 


\section{SPECIFIC CONDITIONS FOR BIOFUEL PRODUCTION DEVELOPMENT IN CASE OF BIOMASS}

There is a correlation between the economic growth, intensification of agricultural production and stronger impact on natural environment. Production of biofuels and bioenergy is one of public goods provided by agriculture in result of greenhouse gases reduction (GHG) and impact on natural environment [Daniłowska 2015]. Many authors present mechanism of reducing the agriculture impact on natural environment in connection with biomass production development needed for energy generation. It mainly results from reduction of GHG general emission, carbon deposition from atmosphere but also from management of agriculture production waste and food production waste. It is one element of the sustainable intensification of agriculture [Dressler et. al. 2012, Gołębiewska and Pajewski 2016, Jarosz and Faber 2016, Lenerts 2015, Pajewski 2016, Popluga et al. 2015, Popluga and Feldmane 2016, Rokicki 2016]. Some authors state that production of first generation biofuels contributes to net reduction of GHG emission to a very limited extent, but it could generate negative impact resulting from introduction of agricultural monocultures [Żołądkiewicz 2016]. As a result, more and more attention is paid and more support provided to use the second generation biofuels or other cheap energy sources, e.g. wind turbines, photovoltaic cells [Eriksson et al. 2016, Jefremov and Rubanovsakis 2015, Popluga and Feldmane 2016, Woon et al. 2016]. The agriculture biofuels production is still a kind of social innovation [Melece 2015] because production of renewable energy from the traditional solid biomass (timber) is still better developed in many EU countries [Krievina and Melece 2016].

Further development of the agricultural production of biofuels mostly results from the environmentally-friendly policy conducted by Member States [Jefremov and Rubanovsakis 2015, Gołębiewski 2014, Pelse and Lescevica 2016], including activities aimed at supporting energy micro-installations development [Chodkowska-Miszczuk 2015] that will cause income diversification in agricultural holdings and economic risk reduction [Wicki and Wicka 2016, Wicka (ed.), 2013].

The most important obstacles, as far as further development of the agricultural production of biofuels based on biomass is concerned, are the following: high cost of investment in production facilities [Gołasa 2016, Melece 2015, Wielewska 2016a, 2016b] and still high cost of energy from renewable sources [Rokicki 2016]. The power production cost is lower when combined heat and power unit (CHP) is used [Dressler et. al. 2012]. The results confirm that renewable energy production is cost-effective when fossil fuels prices remain high [Jasiulewicz and Gostomczyk, 2016, Bórawski et al. 2016]. In case of biogas there is also strong confirmation that such prodiuction is energetically efficient [Jankowski at al. 2016].

\section{RESEARCH RESULTS}

In Poland, the agriculture bio-energy production includes three types of fuels: bioethanol, biodiesel and biogas. Biodiesel production increased in Poland in 2008 when subsidies were introduced. The agriculture biogas energy share in total energy supply was included in statistics in 2011 for the first time and its share in total bioenergy supply is very small. The energy production is shown in table 2. 
Table 2. Production of modern bioenergy from agricultural feedstocks in Poland in years 2005-2016

\begin{tabular}{lrccc}
\hline \multirow{2}{*}{ Year } & \multicolumn{4}{c}{ Production of energy from agricultural resources in TJ } \\
\cline { 2 - 5 } & biogas & biodiesel & bioethanol & total \\
\hline 2005 & - & 2471 & 2404 & 4875 \\
2006 & - & 3423 & 3542 & 6965 \\
2007 & - & 1822 & 2792 & 4614 \\
2008 & 107 & 9943 & 2459 & 12509 \\
2009 & 188 & 14010 & 3838 & 18036 \\
2010 & 334 & 14584 & 4538 & 19456 \\
2011 & 634 & 13974 & 4057 & 18665 \\
2012 & 1463 & 23247 & 5124 & 29834 \\
2013 & 2084 & 24217 & 5098 & 31399 \\
2014 & 2811 & 27343 & 3812 & 33966 \\
2015 & 3413 & 34479 & 4696 & 42588 \\
2016 & 3504 & 33319 & 5275 & 42098 \\
\hline
\end{tabular}

Source: author's calculation based on CSO data [GUS 2009, 2014, 2017].

Biodiesel prevails in the biofuels production mix. Since 2008, the biodiesel share in total production of energy generated from agricultural raw materials is ca. $80 \%$. Biofuels of high share in renewable fuels production are made from first generation of feedstock. During biogas production, the second generation raw materials can be used and its percentage in energy production increased from 1\% in 2008 to $8 \%$ in 2016 . Energy from renewable sources provides $12 \%$ of total energy consumption in Poland and bioenergy from agricultural sources is only $1.5 \%$ of energy consumption.

In 2011, in biogas production 0.5 mil tons of raw material was used and in 2016 eventually 3.2 mil tons of raw material was used. There is no data for the previous years. $74 \%$ of raw material for biogas production was agricultural wastes and food industry wastes. Ca. $30 \%$ of raw material were specific plants (mostly maize silage) (tab. 3 ). High percentage of wastes in the mix of raw material used during biogas production means that it is very modern sector where mostly the second generation raw materials are used. There are only 94 agricultural biogas plants in Poland, whereas in Germany there are more than 10000 plants, in France more than 700 and 17000 in whole EU.

Table 3. Structure of feedstock used in agricultural biogas plant in Poland in 2011-2016

\begin{tabular}{ccccc}
\hline Year & \multicolumn{4}{c}{ Structure of feedstock used in agricultural biogas plant in percent } \\
\cline { 2 - 5 } & $\begin{array}{c}\text { agriculture } \\
\text { wastes }\end{array}$ & $\begin{array}{c}\text { wastes form food } \\
\text { processing industry }\end{array}$ & $\begin{array}{c}\text { agriculture } \\
\text { crops }\end{array}$ & others* \\
\hline 2011 & 59 & 11 & 28 & 2 \\
2012 & 41 & 28 & 31 & 0 \\
2013 & 31 & 43 & 26 & 0 \\
2014 & 29 & 40 & 31 & 0 \\
2015 & 27 & 47 & 26 & 0 \\
2016 & 28 & 47 & 24 & 1 \\
\hline
\end{tabular}

* in years $2012-2015$ less than $0.5 \%$.

Source: author's calculation based on data from AMA reports for years 2011-2015. 
Area of crops used as raw material in agricultural biogas plants in 2016 was only 18000 hectare $(0.17 \%$ of the arable land area). Use of slurry in agricultural biogas plants is equal to $0.7 \%$ of the total production. The importance of the use of waste in agricultural biogas plants is therefore relatively low in the overall amount of waste. Similarly, biogas production does not compete with food production. Agricultural crops used for bioethanol and biodiesel production occupy much bigger area. For 2016 it was calculated that the total net area of such crops was equal to ca. 574100 hectares; while in 2005, the total area was equal to 97200 hectares and 300100 hectares in 2010 (fig. 3). In the years 2010-2016, 50 to $80 \%$ of rapeseed production in Poland was processed to biodiesel. In case of bioethanol production, only $2 \%$ of cereals was used to bioethanol production.

Figure 3. Area of crop for biofuels production in Poland in years 2005-2016

Source: author's calculation.

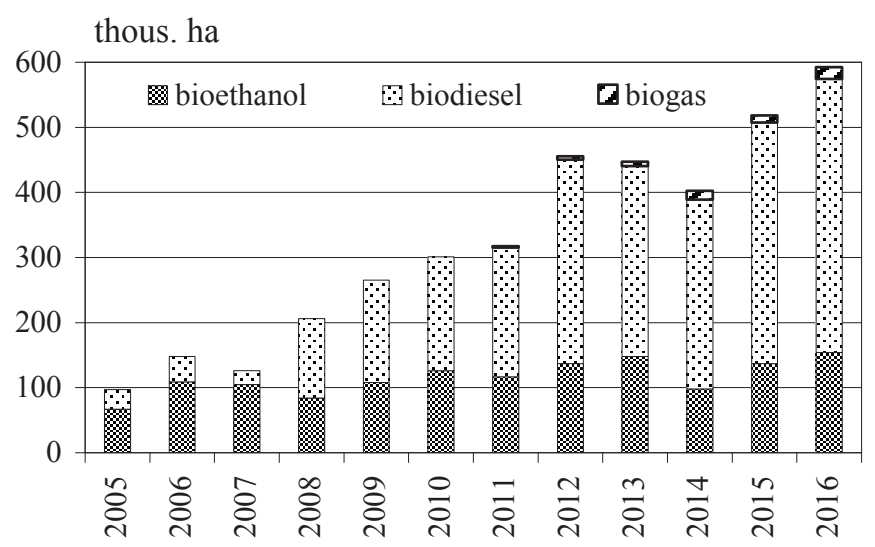

Production area of agricultural raw materials used for bioenergy production significantly increased since 2008 when subsidies for rapeseed production to be used to generate energy were introduced. Bioethanol production to be used as biofuel is not cost-effective without subsidies. Total arable land area used for production of raw materials for production of bioenergy from has increased. In 2016, the area where agricultural energy raw materials were produced was equal to ca. $5.6 \%$ of the total arable land area. The percentage of land used for energy crops was systematically increasing. In 2008, it was $1.8 \%$. The average

Figure 4. Share of arable land allocated for energy crops in Poland in years 2005-2016 Source: author's calculation.

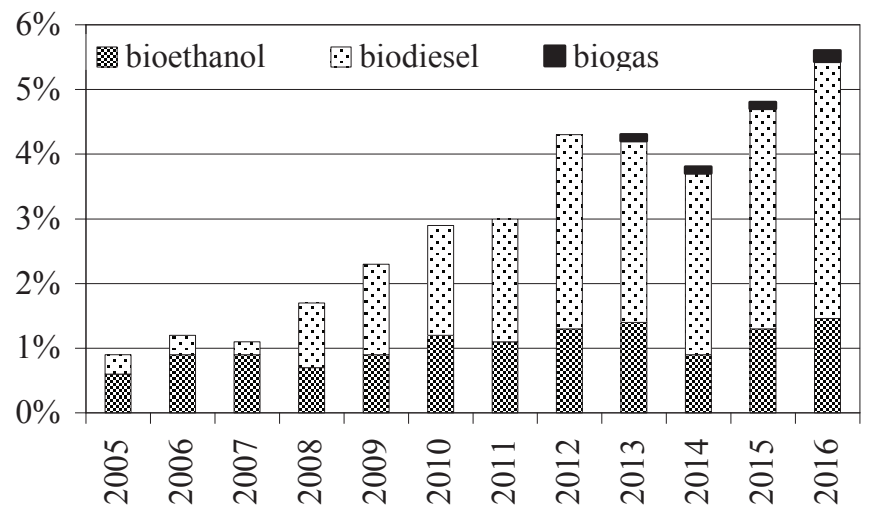


yearly increase rate was $13 \%$ in 2008-2016. Since 2012, the growth rate slowdown can be also observed. This suggests that the reached level shall be maintained (fig. 4).

Observed high percentage of land used for production of energy crops means that bioenergy production competes with food production. In Poland, the quantity of the food produced exceeds domestic demand; nevertheless, permanently increasing area used for production of energy crops makes more difficult to increase e.g. animal production or food export [Grontkowska and Wicki 2015].

\section{CONCLUSIONS}

1. Renewable energy production grows all over the world. In the recent years, the fastest increase can be noticed in photovoltaic cells energy production. Importance of energy from biomass is still high and equal to even 14\%.

2. Ca. $9 \%$ of biomass used for energy production is delivered from agriculture, but as far as production of modern bioenergy is concerned, the agricultural raw materials constitute major part.

3. Production of energy from agricultural raw materials competes with food and feed production. It is then recommended to use the second generation raw materials, mostly by-products and wastes as source of biomass.

4. In Poland, the renewable energy constitutes ca. $12 \%$ of energy consumption and bioenergy from agricultural biomass constitutes only $1.5 \%$ of energy consumption.

5. More than $90 \%$ of the agricultural bioenergy in Poland is produced from raw materials which can be also used for food production (cereals, rapeseed). Up to 5.6\% (591 900 hectares) of the arable land area is used for production of energy raw materials, mostly rapeseed.

6. Bioenergy production in Poland competes with food production; yet, it does not limit food availability but reduces forage production capacity as well as food export capacity.

7. In Poland, it is recommended to support development of systems using the second generation energy raw materials and to reduce production of energy from agricultural raw materials which can be used for food or feed production.

\section{BIBLIOGRAPHY}

ARR, 2012: Sprawozdanie z działalności Agencji Rynku Rolnego w 2011 roku (The Report on the Activity of Agricultural Market Agency in 2011), Warszawa, Agencja Rynku Rolnego, p. 231.

ARR, 2013: Sprawozdanie z działalności Agencji Rynku Rolnego w 2012 roku (The Report on the Activity of Agricultural Market Agency in 2012), Warszawa, Agencja Rynku Rolnego, p. 223.

ARR, 2014: Sprawozdanie z działalności Agencji Rynku Rolnego w 2013 roku (The Report on the Activity of Agricultural Market Agency in 2013), Warszawa, Agencja Rynku Rolnego, p. 217.

ARR, 2015: Sprawozdanie z działalności Agencji Rynku Rolnego w 2014 roku (The Report on the Activity of Agricultural Market Agency in 2014), Warszawa, Agencja Rynku Rolnego, p. 231.

ARR, 2016: Sprawozdanie z działalności Agencji Rynku Rolnego w 2015 roku (The Report on the Activity of Agricultural Market Agency in 2015), Warszawa, Agencja Rynku Rolnego, p. 269.

ARR, 2017: Sprawozdanie z działalności Agencji Rynku Rolnego w 2016 roku (The Report on the Activity of Agricultural Market Agency in 2016), Warszawa, Agencja Rynku Rolnego, p. 291. 
Bórawski Piotr, Rafał Wyszomierski, Aneta Bełdycka-Bórawska, Krzysztof Jankowski, 2016: Ocena opłacalności wykorzystania biomasy na cele energetyczne ze szczególnym uwzględnieniem peletu (Evaluation of Profitability Use of Biomass for Energy Purposes With Particular Regard Paid to Pellet), „Roczniki Naukowe SERiA”, vol. XVIII, no 2, p. 296-302.

Chodkowska-Miszczuk Justyna, 2015: Biogazownie rolnicze w rozwoju małoskalowych instalacji odnawialnych źródet energii w Polsce (Agricultural Biogas Plants in the Development of SmallScale Renewable Energy Instalations in Poland), ,Roczniki Naukowe Ekonomii Rolnictwa i Rozwoju Obszarów Wiejskich", vol. 102, no. 1, p. 97-105.

Daniłowska Alina. 2015: Provision of Public Goods by Agriculture in Poland, "Economic Science for Rural Development", no. 37, p. 142-151.

Dressler Daniela, Achim Loewen, Michael Nelles, 2012: Life Cycle Assessment of the Supply and Use of Bioenergy: Impact of Regional Factors on Biogas Production, "International Journal of Life Cycle Assess", no. 17, p. 1104-1115, https://doi.org/10.1007/s11367-012-0424-9.

Eriksson Ola, Mattias Bisaillon, Marten Haraldsson, Johan Sundberg, 2016: Enhancement of Biogas Production From Food Waste and Sewage Sludge - Environmental and Economic Life Cycle Performance, "Journal of Environmental Management", no. 175, p. 33-39, https://doi. org/10.1016/j.jenvman.2016.03.022.

European Communities, 2009: Directive 2009/28/EC of the European Parliament and of the Council of 23 April 2009 on the promotion of the use of energy from renewable sources and amending and subsequently repealing Directives 2001/77/EC and 2003/30/EC, http://data.europa.eu/eli/ $\operatorname{dir} / 2009 / 28 / \mathrm{oj}$.

Gołasa Piotr, 2015: Agricultural Biogas Production and the Development of Prosumer Energy in Poland, "Economic Science for Rural Development", no. 37, p. 134-141.

Gołębiewska Barbara, Tomasz Pajewski, 2016: Negatywne skutki produkji rolniczej i możliwosci ich ograniczania (The Negative Effects of Agricultural Production and The Possibility of Its Limitation), "Roczniki Naukowe SERiA", vol. XVIII, no. 3, p. 76-81.

Gołębiewski Jarosław, 2014: Biogospodarka jako inteligentna specjalizacja regionów w Polsce (Bioeconomy as a Smart Specialization of Regions in Poland), ,, Przedsiębiorczość i Zarzadzanie (Entrepreneurship and Management), vol. 15, z. 8, part 1, p. 55-69, http://piz.san.edu.pl/ docs/e-XV-8-1.pdf.

Grontkowska Anna, Ludwik Wicki, 2015: Zmiany znaczenia agrobiznesu w gospodarce $i$ w jego wewnętrznej strukturze (Changes in the Importance of Agribusiness in the Economy and Its Internal Structure), „Roczniki Naukowe Ekonomii Rolnictwa i Obszarów Wiejskich”, vol. 102 , no. 3, p. 21-32.

GUS, 2009: Energia ze źródet odnawialnych w 2008 roku (Energy from Renewable Sources in 2008), Warszawa: Główny Urząd Statystyczny (Central Statistical Office), p. 60.

GUS, 2014: Energia ze źródet odnawialnych w 2013 roku (Energy from Renewable Sources in 2013, Warszawa: Główny Urząd Statystyczny (Central Statistical Office), p. 72.

GUS, 2017: Energia ze źródel odnawialnych w 2016 roku (Energy from Renewable Sources in 2016), Warszawa: Główny Urząd Statystyczny (Central Statistical Office), p. 74.

IPCC, 2012: Renewable Energy Sources and Climate Change Mitigation. Special Report of the Intergovernmental Panel on Climate Change, Edenhofer Ottmar, Ramón Pichs-Madruga, Youba Sokona, Kristin Seyboth, Patrick Eickemeier, Patrick Matschoss, Gerrit Hansen, Susanne Kadner, Steffen Schlömer, Timm Zwickel, Christoph von Stechow (eds.), New York: Cambridge University Press, p. 1076.

Jankowski Krzysztof, Bogdan Dubis, Wojciech Budzyński, Piotr Bórawski, Katarzyna Bułkowska, 2016: Energy efficiency of crops grown for biogas production in a large-scale farm in Poland, „Energy”, no. 109, p. 277-286.

Jarosz Zuzanna, Antoni Faber, 2016: Możliwości i ograniczenia emisji rolniczych z uprawy kukurydzy przeznaczonej do produkcji bioetanolu (The Possibility of Agricultural Emmision Limitations From Corn Cultivation on Bioethanol), „Roczniki Naukowe SERiA”, vol. XVIII, no. 3, p. 120-126. 
Jasiulewicz Michał, Waldemar Gostomczyk, 2016: Economic Efficiency of the Utilization of Local Biomass for Energy Purposes, "Roczniki Naukowe SERiA", vol. XVIII, no. 1, p. 90-97.

Jefremov Vladimir, Aleksandrs Rubanovskis, 2015: Electric Power Sector Development Potential, "Economic Science for Rural Development", no. 39, p. 253-263.

Krievina Agnese, Ligita Melece, 2016: Comparison of the Consumption of Wood Pellets Between Latvia and Other EU Countries, "Economic Science for Rural Development", no. 41, p. 210-218.

Lenerts Arnis, 2015: Development of Sustainable Intensification Evaluation Methodology for Farmlands in Latvia, "Economic Science for Rural Development", no. 37, p. 160-170.

Nelson Gerald, 2010: Are Biofuels the Best Use of Sunlight? [in] Handbook of Bioenergy Economics and Policy, eds. Khanna Madhu, Jürgen Schefran, David Zilberman, New York:Springer, https://doi.org/10.1007/978-1-4419-0369-3.

OECD, FAO, 2015: OECD-FAO Agricultural Outlook 2015, OECD Publishing, Paris, https://doi. org/10.1787/agr_outlook-2015-en.

OECD, FAO, 2016: OECD-FAO Agricultural Outlook 2016-2025. Paris: OECD Publishing, https:// doi.org/10.1787/agr outlook-2016-en.

Pajewski Tomasz 2016: Environmental Changes in the Polish Agriculture - Toward the Bio-Economy, "Economic Science for Rural Development', no. 41, p. 243-251.

Pelse Modrite, Maira Lescevica, 2016: Smart Specialization Assessment in Latvia, "Economic Science for Rural Development", no. 42, p. 126-131.

Popluga Dina, Kaspars Naglis-Liepa, Arnis Lenerts, 2015: Latvia's Progress towards Agricultural GHG Mitigation, [in] Proceedings of the 25th NJF Congress. Nordic View to Sustainable Rural Development. Riga, NJF Latvia, p. 265-269.

Popluga Dina, Liga Feldmane, 2016: Development of Sustainable Living Environment in the Cities Through the Bioeconomy, "Economic Science for Rural Development', no. 41, p. 260-265.

REN21, 2016: Renewables 2016. Global Status Report, Paris: REN21 Secretariat, p. 271.

Rokicki Tomasz, 2016: Sustainable Development in Energy Sector in the European Union Countries, "Economic Science for Rural Development", no. 43, p. 108-115.

TechNavio, 2015a: Global Agroscience Market, Infiniti Research Limited, p. 70.

TechNavio, 2015b: Global Biorefinery Market 2015-2019, Infiniti Research Limited, p. 117.

Valentine John, John Clifton-Brown, Astley Hastings, Paul Robson, Gordon Allison, Pete Smith, 2012: Food vs. fuel: the use of land for lignocellulosic 'next generation' energy crops that minimize competition with primary food production, "Global Change Biol Bioenergy", 4: 1-19, doi: 10.1111/j.1757-1707.2011.01111.x.

Wicka Aleksandra (ed.), 2013: Czynniki i możliwosci ograniczania ryzyka w produkcji roślinnej poprzez ubezpieczenia (Factors and Possibilities of Reducing the Risk of Crop Production Using Insurance), Warszawa: Wydawnictwo SGGW, p. 271.

Wicki Ludwik, Aleksandra Wicka, 2016: Bio-Economy Sector in Poland and Its Importance in the Economy, "Economic Science for Rural Development", no. 41, p. 219-228.

Wielewska Izabela, 2016a: Przeznaczenie odnawialnych źródel energii na obszarach wiejskich województwa pomorskiego (Intended Use of Renewable Energy Sources in Rural Areas of the Pomeranian Province), „Roczniki Naukowe SERiA”, vol. XVIII, no. 5, p. 274-280.

Wielewska Izabela, 2016b: Position of Energy Obtained from Agricultural Biogas in Sustainable Power Industry, "Economic Science for Rural Development", no. 42, p. 179-185.

Woon Kok, Irene Lo, Sam Chiu, Dickson Yan, 2016: Environmental Assessment of Food Waste Valorization in Producing Biogas for Various Types of Energy Use Based on LCA Approach, "Waste Management", no. 50, p. 290-299, https://doi.org/10.1016/j.wasman.2016.02.022.

Żołądkiewicz Agnieszka, 2016: Ekonomiczno-ekologiczne aspekty produkcji biopaliw ciektych (Economic and Ecological Aspects of the Production of Liquid biofuels), "Roczniki Naukowe SERiA", vol. XVIII, no. 3, p. 427-431. 


\section{Ludwik Wicki}

\section{ZMIANY POWIERZCHNI PRODUKCJI ROŚLIN ENERGETYCZNYCH W POLSCE}

\section{Streszczenie}

Celem opracowania jest ocena, czy w Polsce produkcja nowoczesnych biopaliw wytwarzanych z surowców rolniczych konkuruje z produkcją żywności. W pracy wykorzystano dane gromadzone przez Glówny Urząd Statystyczny i Agencje Rynku Rolnego (ARR). Wykorzystano dane dotyczace powierzchni gruntów ornych w Polsce, plonów wybranych roślin, pogłowia zwierzą oraz dane o ilości i strukturze produkcji energii oraz o wielkości produkcji biogazu rolniczego, bioetanolu i biodiesla. Dane dotyczace ilości surowców zużywanych w produkcji biogazu rolniczego pozyskano z ARR. Analiza objęto lata 2005-2016. Produkcja bioenergii w oparciu o surowce pochodzenia rolniczego silnie wzrastała w analizowanym okresie, z 5 TJ w 2005 roku to 42 TJ w 2016 roku. Około 92\% energii wytwarzanej z surowców rolniczych stanowi bioetanol i biodiesel, które sa produkowane z surowców pierwszej generacji. Produkcja ta konkuruje więc z produkcją żywności. Biogaz stanowi tylko 8\% energii produkowanej z surowców rolniczych. W produkcji biogazu surowce drugiej generacji, czyli odpady stanowity aż $75 \%$ wsadu. Udziat powierzchni gruntów ornych przeznaczanych do produkcji surowców do wytwarzania biopaliw wynosit 5,6\% w 2016 roku. W 2005 roku było to 1,5\%. Oznacza to, że w Polsce produkcja bioenergii z surowców rolniczych konkuruje z produkcja żywności i pasz, a dalszy jej wzrost nie jest pożądany. Niemniej, przy spadku rozmiarów produkcji zwierzęcej jest to szansa na zagospodarowanie nadwyżek ziemi i produkcji. W przyszłości powinny być podejmowane działania mające na celu zwiększenie wykorzystania surowców drugiej generacji w produkcji bioenergii, a zużycie surowców pierwszej generacji powinno być, w miarę możliwości, ograniczane.

Correspondence address:

Prof. Ludwik Wicki, Ph.D. (orcid.org/0000-0002-7602-8902)

Warsaw University of Life Science - SGGW

Faculty of Economic Sciences, Department of Economics and Organisation of Enterprises Nowoursynowska Str., 166, 02-787 Warsaw e-mail: ludwik_wicki@sggw.pl 